\title{
Příspěvek k poznání vodní malakofauny Hrubého Jeseníku, Rychlebských hor, Zlatohorské vrchoviny a Žulovské pahorkatiny (severní Morava, Česká republika)
}

\author{
Contribution to the knowledge of aquatic molluscs of the Hrubý Jeseník \\ Mountains, the Rychlebské hory Mountains, the Zlatohorská vrchovina \\ Highlands and the Žulovská pahorkatina Highlands (Northern Moravia, Czech \\ Republic)
}

\author{
Luboš Beran \\ Správa chráněné krajinné oblasti Kokořínsko, Česká 149, CZ-27601 Mělník, Česká republika, e-mail: \\ beran@schkocr.cz
}

\section{Úvod}

Oblast severně a severozápadně od Hrubého Jeseníku u hranic s Polskem je z pohledu znalostí o vodní malakofauně jedním z mnoha téměř „bílých míst“, nebot' množství údajů z této oblasti je mizivé a z řady mapových polí pro sítové mapování fauny neexistuje žádný údaj o výskytu vodních měkkýšů. $Z$ tohoto důvodu jsem do této oblasti směřoval svůj orientační malakozoologický výzkum v letech 2000 a 2001 a zejména v roce 2003. Vzhledem k tomu, že se v mnoha případech jednalo o první nálezy řady vodních měkkýšů, tak jsem si dovolil výsledky tohoto průzkumu předložit $\mathrm{v}$ této práci tak, aby se staly vodítkem pro další malakozoologický výzkum.

\section{Metodika a materiál}

Průzkum byl proveden celkem na 56 lokalitách v letech 2000, 2001 a 2003. Sběr byl na většině lokalit prováděn kombinací vizuální metody a odběrů z vegetace či sedimentu za pomoci kovového kuchyňského cedníku (průměr cedníku $20 \mathrm{~cm}$, velikost ok $0,5-1 \mathrm{~mm}$ ).

Zejména $\mathrm{v}$ případě špatně určitelných druhů, druhů jejichž taxonomické postavení je $\mathrm{v}$ současnosti nejasné a druhů vzácných (ohrožené, zavlečené) byla alespoň část sběru uložena do sbírky autora. U měkkýšů determinovatelných pouze pomocí lupy (např. většina druhů r. Pisidium) byl materiál determinován až v laboratoři. Stejně tak bylo postupováno u měkkýšů, k jejichž determinaci je nutná pitva (některé druhy z čeledi Hydrobiidae, Planorbidae a Lymnaeidae). K pitvě bylo použito jedinců usmrcených přelitím horkou vodou a posléze fixovaných v $70 \%$ ethanolu.

Systém a nomenklatura jsou převzaty z práce BERAN (2002).

\section{Charakteristika území}

Hrubý Jeseník

Rozsáhlá hornatina ležící severně od města Jeseník. Nejvyšším vrcholem je Praděd (1491 m n.m.). Řada dalších vrcholů přesahuje $1000 \mathrm{~m}$ n.m. Značná část území je součástí CHKO Jeseníky. Území je z větší části pokryto lesy. Z výjimkou okrajových částí jsou z vodních stanovišt' zastoupeny zejména prameniště a rychle tekoucí potoky a ř́ičky.

Rychlebské hory

Rychlebské hory jsou hornatinou s rozlohou blížící se $300 \mathrm{~km}^{2}$ a střední nadmořskou výškou 645 m. Nejvyšším vrcholem je Smrk (1125 m n.m.). Táhnou se v pásu podél státní hranice od města Jeseník až po Zlatý Stok v Polsku. Stejně jako v př́ípadě Hrubého Jeseníku jsou v této oblasti nejčastějšími vodními stanovišti rychle tekoucí vodní toky a prameniště. 
Zlatohorská vrchovina

Zlatohorská vrchovina navazuje na severní okraj Hrubého Jeseníku. Její rozloha je více než $500 \mathrm{~km}^{2}$ a střední nadmořská výška $496 \mathrm{~m}$.

Žulovská pahorkatina

Toto území navazuje na pás Rychlebských hor a postupně se snižuje do Polska do Pradoliny Nisy. Především oblast severně od Vidnavy má téměř nížinný charakter a nadmořská výška se zde blíží k 220 m n.m.. Tato oblast je ze studovaných území nejbohatší na stojaté vody. Kromě několika rybníků a řady drobných rybníčků a vodních nádrží je zde řada vodních ploch vzniklých po těžbě (kaolín, písek, žula).

\section{Přehled lokalit}

$\mathrm{V}$ této části jsou uvedeny popisy jednotlivých lokalit. Údaje jsou řazeny následovně: číslo lokality, název nejbližší obce, kód pole pro faunistické mapování (cf. BUCHAR 1982), lokalizace a popis lokality, datum průzkumu. Lokality jsou řazeny chronologicky. Ve všech př́ípadech byl materiál sebrán autorem.

1 - Vidnava, 5669, tůně a mokřady v PR Vidnavské mokřiny severně od Vidnavy na státní hranici s Polskem, 26. 9. 2000; 2 - Vidnava, 5669, potok vytékající z PR Vidnavské mokřiny severně od Vidnavy, 27. 9. 2000; 3 - Vidnava, 5669, zarostlé tůňky cca 2,5 km východně od Vidnavy v bývalém kaolínovém lomu, 27. 9. 2000; 4 - Vidnava, 5669, velká tůn̆ cca 2,5 km východně od Vidnavy v bývalém kaolínovém lomu, 27. 9. 2000; 5 - Mikulovice, 5669, mokřad u nové silnice u nádraží ČD, 27. 9. 2000; 6 - Zlaté Hory, 5770, horní rybníček v PP Černé jezero 1,5 km jihozápadně od Zlatých Hor, a) 27. 9. 2000, b) 11. 10. 2001; 7 - Zlaté Hory, 5770, dolní rybníček v PP Černé jezero 1,5 km jihozápadně od Zlatých Hor, a) 27. 9. 2000, b) 11. 10. 2001; 8 - Zlaté Hory, 5770, velká vodní nádrž severně od Zlatých Hor u státní hranice s Polskem, 27. 9. 2000; 9 - Zlaté Hory, 5770, rybníček mezi velkou vodní nádrží a potokem severně od Zlatých Hor u státní hranice s Polskem, 27. 9. 2000; 10 - Zlaté Hory, 5770, větší rybník na státní hranici s Polskem západně od hraničního přechodu, 11. 10. 2001; 11 - Zlaté Hory, 5770, malý a částečně vypuštěný rybníček pod větším rybníkem na státní hranici s Polskem západně od hraničního přechodu, 11. 10. 2001; 12 - Písečná, 5769, pískovna (téměř bez vegetace) severně od Písečné, 11. 10. 2001; 13 - Supíkovice, 5769, lom u Supíkovic, 11. 10. 2001; 14 - Rejvíz, 5769, prameniště a drobná tůňka na žluté turistické značce u chat 400-500 m jižně od parkoviště v Rejvízu před okrajem lesa v NPR Rejvíz, 28. 4. 2003; 15 - Rejvíz, 5769, drobný potůček ústící do Černé Opavy v NPR Rejvíz asi $500 \mathrm{~m}$ severně od Velkého mechového jezírka, 28. 4. 2003; 16 - Bílý Potok, 5568, mokřad u drobného potůčku severně od obce Bílý Potok asi $500 \mathrm{~m}$ před přechodem státní hranice do Polska, 29. 4. 2003; 17 - Bílý Potok, 5568, drobný potůček severně od obce Bílý Potok asi $500 \mathrm{~m}$ před přechodem státní hranice do Polska, 29. 4. 2003; 18 - Bílý Potok, 5567, potok podél rybníčka na severním okraji obce Bílý Potok, 29. 4. 2003; 19 - Horní Hoštice, 5567, potok v západní části Horních Hoštic u odbočky polní cesty do Kotlinky (po proudu pod kostelem), 29. 4. 2003; 20 - Horní Hoštice, 5567, tůňka u potoka v lese na západním okraji obce Horní Hoštice nad posledním domem, 29. 4. 2003; 21 - Horní Hoštice, 5567, Hoštický potok v Kotlince před odbočením lesní cesty do Hoštic cca 1,5 km východně od Vysokého kamene (691 m n. m.), 29. 4. 2003; 22 - Račí Údolí, 5668, Račí potok v lese asi $100 \mathrm{~m}$ od okraje lesa v Račím Údolí, 29. 4. 2003; 23 - Račí Údolí, 5667, Račí potok na odbočce k zrrícenině hradu Rychleby, 29. 4. 2003; 24 - Račí Údolí, 5667, drobný prŕítok Račího potoka od zř́iceniny hradu Rychleby asi $100 \mathrm{~m}$ před ústím do Račího potoka, 29. 4. 2003; 25 Jeseník, 5769, Vrchovištní potok asi 400-500 m před ústím do Bělé, 29. 4. 2003; 26 Karlova Studánka, 5969, jezírko v parku v Karlově Studánce, 30. 4. 2003; 27 - Karlova Studánka, 5669, tůňky a mokřady u parku v Karlově Studánce, 30. 4. 2003; 28 - Jeseník, 5769, nejhořejší rybník ze soustavy rybníků v údolí západně od Bukovic, 30. 4. 2003; 29 - 
Jeseník, 5769, mokřad pod nejhořejším rybníkem ze soustavy rybníků v údolí západně od Bukovic, 30. 4. 2003; 30 - Jeseník, 5769, malé prameniště pod hrází nejhořejšího rybníka ze soustavy rybníků v údolí západně od Bukovic, 30. 4. 2003; 31 - Jeseník, 5769, rybník 2. odshora ze soustavy rybníků v údolí západně od Bukovic, 30. 4. 2003; 32 - Jeseník, 5769, rybník 3. odshora ze soustavy rybníků v údolí západně od Bukovic, 30. 4. 2003; 33 - Jeseník, 5769 , mokřad a tůňky pod hrází rybníka 3. odshora ze soustavy rybníků v údolí západně od Bukovic, 30. 4. 2003; 34 - Jeseník, 5769, louže v louce asi 100 m před prvním domem v Lázních Jeseník u silnice Jeseník - Lázně Jeseník, 1. 5. 2003; 35 - Jeseník, 5769, pramenná stružka pod modrou a zelenou turistickou značkou asi $100 \mathrm{~m}$ před Žofiiným pramenem v Lázních Jeseník, 1. 5. 2003; 36 - Jeseník, 5769, drobný potůček tekoucí z Lázní Jeseník k železniční stanici Jeseník mezi prvními domky v Jeseníku, 1. 5. 2003; 37 - Jeseník, 5769, potok Staříč u mostu asi 1,7 km před ústím do Bělé, 1. 5. 2003; 38 - Jeseník, 5769, menší rybník u potoka Staříč na stejné straně potoka jako železniční trat' asi $300 \mathrm{~m}$ jihozápadně od železniční stanice Jeseník, 1. 5. 2003; 39 - Jeseník, 5769, větší vodní nádrž (rybník) u potoka Staříč asi 350 m severoseverozápadně od železniční stanice Jeseník na opačné straně potoka než železniční trat', 1. 5. 2003; 40 - Adolfovice, 5869, Šumný potok asi 50 m před ústím do Bělé, 1. 5. 2003; 41 - Adolfovice, 5869, Javořický potok asi 300 m před ústím do Bělé, 1. 5. 2003; 42 - Adolfovice, 5869, drobný potok asi 50 m před ústím do Javořického potoka (a 250 m před ústím Javořického potoka do Bělé), 1. 5. 2003; 43 - Bergov, 5668, drobný rybníček u silnice (ten ze 2, který je blíže Uhelné) na jihovýchodním okraji Bergova, 2. 5. 2003; 44 Bergov, 5668, menší rybníček u silnice na jihovýchodním okraji Bergova (ten ze 2, který je dále Uhelné), 2. 5. 2003; 45 - Uhelná, 5668, větší pískovna (lom) u Uhelné, 2. 5. 2003; 46 Uhelná, 5668, menší pískovna (lom) u Uhelné, 2. 5. 2003; 47 - Javorník, 5667, mokřad nad vypuštěným lesním rybníčkem v Komáří dolině na červené turistické značce asi $2 \mathrm{~km}$ západně od Javorníku, 2. 5. 2003; 48 - Javorník, 5667, rybníček u lesa (větší ze 2) na červené turistické značce asi 2 km západně od Javorníka, 2. 5. 2003; 49 - Javorník, 5667, rybníček u lesa (menší ze 2) na červené turistické značce asi 2 km západně od Javorníka, 2. 5. 2003; 50 Javorník, 5667, rybník asi 2 km západně od Javorníka, 2. 5. 2003; 51 - Žulová, 5668, Vidnávka v Žulové u železniční stanice, 2. 5. 2003; 52 - Žulová, 5668, Stř́brný potok asi 400 m před ústím do Vidnávky, 2. 5. 2003; 53 - Žulová, 5668, drobný mokřad (louže) v louce na severním svahu Boží hory, 2. 5. 2003; 54 - Žulová, 5668, prameniště v olšině na severním svahu Boží hory, 2. 5. 2003; 55 - Jeseník, 5769, Bělá nad jezem v Bukovicích u lomu, 3. 5. 2003; 56 - Branná, 5868, potok Branná u železniční stanice Branná, 3. 5.2003.

\section{Dosavadní malakologické průzkumy}

Publikovaných údajů o výskytu vodních měkkýšů je velmi málo a týkají se prakticky pouze Hrubého Jeseníku. Údaje o několika málo běžných vodních druzích lze nalézt v pracích LOŽEK (1954), KAPLER (1956), KAPLER (1958) a okrajově také v práci MÁCHA (1962) věnující se měkkýšům Hynčické vrchoviny. Zdrojem nepublikovaných údajů z této oblasti jsou zejména sběry J. Brabence a V. Pflegera uložené v Národním muzeu v Praze a také sbírky S. Máchy ve Slezském muzeu v Opavě. Jeden z prvních historických údajů pochází od J. Petrboka ze začátku 20. století a týká se nálezu perlorodky Margaritifera margaritifera (Linnaeus, 1758) v Černém potoce u Vidnavy. Materiál je uložen v Národním muzeu, stejně jako později sbíraný materiál od J. Brabence, zatímco materiál toho samého druhu od S. Máchy je uložen v Opavě. S. Mácha zkoumal kromě toho i oblast PR Vidnavské mokřiny, která na rozdíl od většiny ostatních lokalit zkoumaných v minulosti poskytuje údaje o výskytu v této oblasti vzácných druhů jako je např. Valvata cristata či Sphaerium corneum.

\section{Výsledky a diskuse}

Přehled zjištěných druhů 
V této části jsou uvedeny výsledky orientačního průzkumu v letech 2000, 2001 a 2003 podle jednotlivých druhů. U každého druhu je uvedeno zoogeografické rozšíření převzaté z práce BERAN (2002) a dále údaje týkající se obývaných stanovišt', poznámky k rozšíření na území ČR a rozšíření ve sledovaném území.

Classis: Gastropoda

Ordo: Neotaenioglossa

Familia: Hydrobiidae

Bythinella austriaca (Frauenfeld, 1857) s.lat. - rozšíření východoalpsko-karpatské. Taxon obývající prameniště a pramenné stružky, který byl nalezen na 2 místech v okolí Jeseníku (lok. č. 30 a 35). Problematika tohoto taxonu (souboru druhů) viz BERAN (2002).

Familia: Valvatidae

Valvata cristata O.F. Müller, 1774 - rozšíření palearktické. Tento druh vyskytující se v hustě zarostlých stojatých vod v nižších polohách byl nalezen pouze v PR Vidnavské mokřiny.

Ordo: Hygrophila

Familia: Acroloxidae

Acroloxus lacustris (Linnaeus, 1758) - rozšíření palearktické. Druh se vyskytuje v pomaleji tekoucích a stojatých vodách a ve sledované oblasti byl zjištěn pouze v PR Vidnavské mokřriny.

Familia: Lymnaeidae

Galba truncatula (O.F. Müller, 1774) - rozšíření holarktické. Běžný druh obývající biotopy na přechodu mezi vodou a souší, tzn. zejména břehy vodních biotopů a mokřady. Tento druh patří k běžným a nejčastěji nalézaným druhům ve zkoumané oblasti.

Stagnicola corvus (Gmelin, 1791) - rozšíření palearktické. Tento druh je vázán především na stojaté a zarostlé vody v nížinách. Byl nalezen pouze v PR Vidnavské mokřriny a tento nález je prakticky jediný v přilehlé části severní Moravy (cf. BERAN 2002).

Radix auricularia (Linnaeus, 1758) - rozšíření palearktické. Obývá velké spektrum biotopů kromě př́liš zarostlých a zazemněných stojatých vod. Ve zkoumaném území není př́lišs vzácná.

Radix peregra (O.F. Müller, 1774) s.str. - rozšíření palearktické. Druh typický pro vyšší a méně úživné polohy, který se vyskytuje $\mathrm{v}$ prameništích, pramenných stružkách, rychle tekoucích potocích a řekách i v málo úživných vodních nádržích. $Z$ těchto důvodů patří mezi nejčastěji zastižené druhy i ve sledované oblasti.

Radix ovata (Draparnaud, 1805) - rozšíření palearktické. Vzácnější druh vyskytující se především v pomalu tekoucích a stojatých vodách v nížinách, který byl nalezen pouze na lok. č. 46.

Lymnaea stagnalis (Linnaeus, 1758) - rozšíření holarktické. Běžný druh stojatých a pomalu tekoucích vod, který se však ve zkoumaném území vyskytuje pouze vzácně a byl zjištěn na 2 lokalitách.

Familia: Physidae

Aplexa hypnorum (Linnaeus, 1758) - rozšíření holarktické. Ubývající druh periodických mokřadů, který byl zjištěn pouze na lok. č. 43.

Familia: Planorbidae

Anisus leucostoma (Millet, 1813) - rozšiřrení palearktické. Druh vyskytující se obvykle v periodických stojatých vodách či na okrajích vodních nádrží. Ve zkoumané oblasti nepatří k vzácným druhům a byl nalezen celkem na 11 lokalitách. 
Gyraulus albus (O.F. Müller, 1774) - rozšíření palearktické. Běžný druh pomaleji tekoucích a stojatých vod, který patří ve zkoumané oblasti k nejčastěji nalezeným druhům.

Gyraulus crista (Linnaeus, 1758) - rozšíření holarktické. Relativně běžný druh stojatých vod, který se občasně vyskytuje i v tekoucích vodách, který byl nalezen na 9 lokalitách.

Hippeutis complanatus (Linnaeus, 1758) - rozšíření palearktické. Běžný druh stojatých a hustěji zarostlých pomaleji tekoucích vod, který byl zjištěn na 6 zkoumaných lokalitách.

Planorbarius corneus (Linnaeus, 1758) - rozširření eurosibiřské. Druh vázaný na nivy větších řek a rybniční oblasti, který byl zjištěn pouze v PR Vidnavské mokřiny.

Ancylus fluviatilis O.F. Müller, 1774 - rozšíření evropské. Běžný druh tekoucích vod, který patří ve zkoumané oblasti $\mathrm{k}$ hojným druhům a v několika případech byl zjištěn i ve vodních nádržích.

Ferrissia clessiniana (Jickeli, 1882) - druh zavlečený pravděpodobně z Jižní Afriky (někteří autoři považují tento druh za evropský) (cf. BERAN 2002). Nález tohoto druhu v pískovně u obce Písečná (lok. č. 12) je velmi překvapující, nebot' se jedná o první nález na severní Moravě (BERAN 2002).

Classis: Bivalvia

Familia: Unionidae

Anodonta anatina (Linnaeus, 1758) - rozšíření eurosibiřské. Běžný velký mlž, který obývá vodní toky i vodní nádrže a ve zkoumané oblasti byl zjištěn na 5 lokalitách (vše stojaté vody).

Familia: Sphaeriidae

Sphaerium corneum (Linnaeus, 1758) s.lat. - rozšíření palearktické. V České republice se jedná o běžného mlže žijícího především v živinami bohatých tekoucích vodách. Ve sledovaném území byl tento druh zastižen pouze v PR Vidnavské mokřiny.

Musculium lacustre (O.F. Müller, 1774) - rozšíření holarktické. Méně často (respektive mozaikovitě) se vyskytující mlž žijící v pomaleji tekoucích a stojatých vodách, který byl zjištěn na 5 lokalitách.

Pisidium milium Held, 1836 - rozšiřrení holarktické. Vzácnější druh žijící především v pomaleji tekoucích a stojatých vodách. Zjištěn byl pouze na lokalitě č. 29.

Pisidium subtruncatum Malm, 1855 - rozšiřrení holarktické. Jeden z nejběžnějších příslušníků rodu Pisidium žijící zejména $\mathrm{v}$ tekoucích vodách. Ve zkoumané oblasti byl překvapivě nalezen pouze na jediné lokalitě.

Pisidium nitidum Jenyns, 1832 - rozšíření holarktické. V ČR poměrně běžný druh, který však byl zastižen pouze v PR Vidnavské mokřiny.

Pisidium obtusale (Lamarck, 1818) - rozšíření holarktické. Typický obyvatel hustě zarostlých stojatých vod. Ve sledované oblasti byl zjištěn pouze na lokalitě č. 43.

Pisidium personatum Malm, 1855 - rozšíření eurosibiřské. Obývá zejména chladnější drobné stojaté vody, prameniště a pramenné stružky a ve zkoumané oblasti nepatří k vzácným druhům.

Pisidium casertanum (Poli, 1791) - pravděpodobně kosmopolitní druh rozšířený na většině vodních stanovišt' u nás, který je nejčastěji nalézaným druhem ve sledovaném území.

\section{Shrnutí}

V letech 2000, 2001 a 2003 byl při orientačním malakozoologickém výzkumu Hrubého Jeseníku, Rychlebských hor, Zlatohorské vrchoviny a Žulovské pahorkatiny (Česká republika, severní Morava) prokázán recentní výskyt celkem 26 druhů vodních měkkýšů (17 plžů, 9 mlžů). Vzhledem k charakteru území jsou nejčastějšími přirozenými stanovišti vodní toky od pramenných stružek po říčky. Většina z těchto vodních toků má bystřinný charakter a jejich malakocenózy jsou tvořeny druhy Galba truncatula, Radix peregra s.str., Ancylus fluviatilis, Pisidium casertanum. Častá jsou také prameniště a drobné tůňky, kde jsou nejčastějšími 
obyvateli opět druhy Galba truncatula, Radix peregra s.str., Pisidium casertanum, ke kterým přistupují Bythinella austriaca s.lat., Anisus leucostoma, Pisidium personatum a v jednom př́ípadě i Pisidium milium. Malakofaunu výrazně obohacují uměle vytvořené vodní nádrže, kterými jsou různě velké rybníčky a také plochy vzniklé v souvislosti s těžbou rozličných surovin. Zatímco druhy Galba truncatula, Radix auricularia, Radix peregra s.str., Anisus leucostoma, Gyraulus albus, Gyraulus crista, Hippeutis complanatus, Musculium lacustre či Pisidium casertanum patřily k poměrně často zjištěným druhům na uvedených stanovištích, tak jiní měkkýši byly nalezeni pouze na jediné lokalitě (např. Radix ovata, Lymnaea stagnalis, Aplexa hypnorum, Pisidium obtusale).

Tabulka 1. Přehled vodních měkkýšů podle lokalit (odhad hustoty populace na $1 \mathrm{~m}^{2}$ plochy obývané uvedeným druhem; $\mathrm{O}$-- ojediněle, méně než 1 jedinec na $1 \mathrm{~m}^{2}, \mathrm{R}$ - roztroušeně, $1-20$ jedinců na $1 \mathrm{~m}^{2}, \mathrm{H}-$ hojně, 20-100 jedinců na $1 \mathrm{~m}^{2}, \mathrm{VH}$ - velmi hojně, více než 100 jedinců na $1 \mathrm{~m}^{2}$ ). Lokality č. 1-28.

Table 1. List of aquatic molluscs according to localities (estimation of density of population; $\mathrm{O}$ - solitary occurrence, less than 1 specimen per 1 square meter, $\mathrm{R}$ - scattered occurrence, 1-20 specimens per 1 square meter, $\mathrm{H}$ - abundant occurrence, 20-100 specimens per 1 square meter, $\mathrm{VH}$ - very abundant occurrence, over 100 specimens per 1 square meter). Localities No. 1-28.

\begin{tabular}{|c|c|c|c|c|c|c|c|c|c|c|c|c|c|c|c|c|c|c|c|c|c|c|c|c|c|c|c|c|}
\hline \multirow[t]{2}{*}{ Druh } & \multicolumn{28}{|c|}{ Lokalita č. } \\
\hline & 1 & 2 & \begin{tabular}{|l|l|l}
3 & 4 \\
\end{tabular} & 5 & $6 a$ & $6 \mathrm{~b}$ & & $7 \mathrm{~b}$ & 89 & 10 & 11 & & & & & 16 & 17 & 18 & 19 & 20 & & & 23 & & 25 & & 27 & 28 \\
\hline \multicolumn{29}{|l|}{ Bythinella austriaca s.lat. } \\
\hline Valvata cristata & $\mathrm{H}$ & & & & & & & & & & & & & & & & & & & & & & & & & & & \\
\hline Acroloxus lacustris & $\mathrm{R}$ & $\mathrm{O}$ & & & & & & & & & & & & & & & & & & & & & & & & & & \\
\hline Galba truncatula & & & $\mathrm{R}$ & $\mathrm{O}$ & & & & & O & & & O & & & & & & & & $\mathrm{R}$ & & & & & $\mathrm{O}$ & & O & \\
\hline Stagnicola corvus & 0 & & & & & & & & & & & & & & & & & & & & & & & & & & & \\
\hline Radix auricularia & 0 & & O & & & & $\mathrm{R}$ & & $\mathrm{RO}$ & $\mathrm{H}$ & $\mathrm{VH}$ & 0 & & & & & & & & & & & & & & & & $\mathrm{O}$ \\
\hline Radix peregra s.str. & & & $\mathrm{R}$ & 0 & $\mathrm{VH}$ & $\mathrm{H}$ & $\mathrm{O}$ & $\mathrm{R}$ & $\mathrm{O}$ & $\mathrm{R}$ & $\mathrm{O}$ & & & $\mathrm{H}$ & & $\mathrm{H}$ & $\mathrm{O}$ & 0 & $\mathrm{R}$ & & & & & & & $\mathrm{O}$ & $\mathrm{R}$ & $\mathrm{O}$ \\
\hline \multicolumn{29}{|l|}{ Radix ovata } \\
\hline Lymnaea stagnalis & $R$ & & & & & & & & & & & & & & & & & & & & & & & & & & & $\mathrm{O}$ \\
\hline \multicolumn{29}{|l|}{ Aplexa hypnorum } \\
\hline Anisus leucostoma & & & & $\mathrm{VH}$ & & & & & $R$ & & & & & $\mathrm{H}$ & & $\mathrm{R}$ & $\mathrm{R}$ & & & $\mathrm{VH}$ & & & & & & & & \\
\hline Gyraulus albus & $\mathrm{R}$ & $\mathrm{O}$ & 0 & & $\mathrm{R}$ & $\mathrm{O}$ & $\mathrm{O}$ & & $\mathrm{RO}$ & $\mathrm{R}$ & $\mathrm{O}$ & $\mathrm{O}$ & & & & & & & & & & & & & & & & $R$ \\
\hline Gyraulus crista & & & & & & & & & $R$ & & $\mathrm{O}$ & & $\mathrm{H}$ & & & & & & & & & & & & & & & \\
\hline Hippeutis complanatus & 0 & & & & & & & & $\mathrm{R}$ & $\mathrm{O}$ & & & & & & & & & & & & & & & & & & \\
\hline Planorbarius corneus & $\mathrm{O}$ & & & & & & & & & & & & & & & & & & & & & & & & & & & \\
\hline Ancylus fluviatilis & & & & & & & & & & $\mathrm{O}$ & & & & & $\mathrm{R}$ & & & & $\mathrm{H}$ & & $\mathrm{O}$ & $\mathrm{O}$ & $\mathrm{O}$ & $\mathrm{O}$ & $\mathrm{O}$ & & & \\
\hline Ferrissia clessiniana & & & & & & & & & & & & 0 & & & & & & & & & & & & & & & & \\
\hline Anodonta anatina & $\mathrm{O}$ & & & & & & & & & $\mathrm{O}$ & & 0 & & & & & & & & & & & & & & & & \\
\hline \multicolumn{29}{|c|}{ Sphaerium corneum s.lat. $\mathrm{H}$ VH } \\
\hline Musculium lacustre & & & & & & $\mathrm{R}$ & & $\mathrm{R}$ & & $\mathrm{H}$ & & & & & & & & & & & & & & & & & & \\
\hline \multicolumn{29}{|l|}{ Pisidium milium } \\
\hline Pisidium subtruncatum & & & & & & & & & & O & & & & & & & & & & & & & & & & & & \\
\hline Pisidium nitidum & $\mathrm{O}$ & $\mathrm{H}$ & & & & & & & & & & & & & & & & & & & & & & & & & & \\
\hline \multicolumn{29}{|l|}{ Pisidium obtusale } \\
\hline Pisidium personatum & & & $\mathrm{R}$ & $\mathrm{O}$ & & & & & & & & & & & & & & & & & & & & & & $\mathrm{O}$ & $\mathrm{R}$ & \\
\hline Pisidium casertanum & & & & & $\mathrm{O}$ & $\mathrm{O}$ & & $\mathrm{O}$ & & $\mathrm{O}$ & & & & & $\mathrm{O}$ & & $\mathrm{O}$ & $\mathrm{O}$ & $\mathrm{O}$ & $\mathrm{R}$ & & & $\mathrm{O}$ & & $\mathrm{O}$ & $\mathrm{O}$ & $\mathrm{R}$ & $\mathrm{R}$ \\
\hline Celkem & 11 & 4 & 42 & 4 & 3 & 4 & 3 & 3 & 45 & 9 & 4 & 5 & 1 & 2 & 2 & 2 & 3 & 2 & 3 & 3 & 1 & 1 & 2 & 1 & 3 & 3 & 4 & 5 \\
\hline
\end{tabular}

Zvláštní pozornost si zaslouží nepůvodní plž Ferrissia clessiniana, který je na Moravě prozatím vzácný a jeho nález v pískovně u obce Písečná je prvním údajem ze severní Moravy. Zvláštní postavení $\mathrm{v}$ přehledu zkoumaných stanovišt' má PR Vidnavské mokřiny. Tato lokalita ( $\check{c} .1$ a 2 ) na hranicích s Polskem má již téměř plně nížinný charakter a řada druhů byla zjištěna pouze zde. Jedná se především o druhy Valvata cristata, Acroloxus lacustris, Stagnicola corvus, Planorbarius corneus a Sphaerium corneum s.lat. 
Tabulka 2. Přehled vodních měkkýšů podle lokalit. Lokality č. 29-56. $\Sigma$ nálezů je uvedena pro všechny lokality od 1 do 56.

Table 2. List of aquatic molluscs according to localities. Localities No. 29-56. $\Sigma$ is for all localities from No 1 to 56.

\begin{tabular}{|c|c|c|c|c|c|c|c|c|c|c|c|c|c|c|c|c|c|c|c|c|c|c|c|c|c|c|c|c|c|}
\hline \multirow[t]{2}{*}{ Druh } & \multicolumn{28}{|c|}{ Lokalita č. } & \multirow{2}{*}{$\Sigma$} \\
\hline & & 930 & 31. & 32 & 33 & 34 & 35 & 36 & 37 & 38 & 39 & & 41 & 42 & 43. & 444 & 45 & & 47 & & & 50 & 515 & & 535 & & & 56 & \\
\hline Bythinella austriaca s.lat. & & $\mathrm{R}$ & & & & & $\mathrm{H}$ & & & & & & & & & & & & & & & & & & & & & & 2 \\
\hline \multicolumn{30}{|l|}{ Valvata cristata } \\
\hline Acroloxus lacustris & & & & & & & & & & & & & & & & & & & & & & & & & & & & & 2 \\
\hline Galba truncatula & & & $\mathrm{O}$ & $R$ & $\mathrm{R}$ & $\mathrm{O}$ & & & & & & $\mathrm{O}$ & & & & & & & & & & $\mathrm{H}$ & $R$ & & & $\mathrm{O}$ & $\mathrm{O}$ & 01 & 17 \\
\hline \multicolumn{30}{|l|}{ Stagnicola corvus } \\
\hline Radix auricularia & & & & & & & & & & & $\mathrm{O}$ & & & & & & $\mathrm{O}$ & $\mathrm{O}$ & & & & & & & & & & & 12 \\
\hline Radix peregra s.str. & & & & $\mathrm{O}$ & $\mathrm{R}$ & & $\mathrm{R}$ & $\mathrm{R}$ & & & & & & $\mathrm{R}$ & & & $\mathrm{O}$ & & $\mathrm{O}$ & & & & $\mathrm{R}$ & $\mathrm{O}$ & & & & & 26 \\
\hline Radix ovata & & & & & & & & & & & & & & & & & & $\mathrm{R}$ & & & & & & & & & & & 1 \\
\hline \multicolumn{30}{|l|}{ Lymnaea stagnalis } \\
\hline Aplexa hypnorum & & & & & & & & & & & & & & & $R$ & & & & & & & & & & & & & & 1 \\
\hline Anisus leucostoma & & & & & & & & & & & $\mathrm{R}$ & & & $\mathrm{R}$ & $\mathrm{H}$ & $\mathrm{R}$ & & & & & & $\mathrm{H}$ & & & & & & & 11 \\
\hline Gyraulus albus & & & $\mathrm{H}$ & $R$ & & & & & & $\mathrm{H}$ & $\mathrm{R}$ & & & & & & $\mathrm{R}$ & $R$ & & & & $\mathrm{H}$ & & & & & & & 20 \\
\hline Gyraulus crista & & & & & & & & & & $\mathrm{O}$ & 0 & & & & $\mathrm{O}$ & $\mathrm{O}$ & & 0 & & & 0 & & & & & & & & 9 \\
\hline Hippeutis complanatus & & & $\mathrm{R}$ & & & & & & & & O & & & & & & $\mathrm{O}$ & & & & & & & & & & & & 6 \\
\hline \multicolumn{30}{|l|}{ Planorbarius corneus } \\
\hline Ancylus fluviatilis & & & & & & & & & $\mathrm{R}$ & & $R$ & $\mathrm{R}$ & $\mathrm{O}$ & $\mathrm{O}$ & & & & & & $\mathrm{R}$ & & & $\mathrm{R}$ & $\mathrm{R}$ & & & $\mathrm{R}$ & $\mathrm{R} 1$ & 18 \\
\hline \multicolumn{30}{|l|}{ Ferrissia clessiniana } \\
\hline Anodonta anatina & & & & & & & & & & & $\mathrm{O}$ & & & & & & $\mathrm{O}$ & & & & & & & & & & & & 5 \\
\hline \multicolumn{30}{|l|}{ Sphaerium corneum s lat. } \\
\hline Musculium lacustre & & & & & & & & & & & & & & & $\mathrm{H}$ & & $\mathrm{O}$ & & & & & & & & & & & & 5 \\
\hline Pisidium milium & 0 & & & & & & & & & & & & & & & & & & & & & & & & & & & & 1 \\
\hline Pisidium subtruncatum & & & $\mathrm{O}$ & & & & & & & & & & & & & & & & & & & & & & & & & & 2 \\
\hline \multicolumn{30}{|l|}{ Pisidium nitidum } \\
\hline Pisidium obtusale & & & & & & & & & & & & & & & 0 & & & & & & & & & & & & & & 1 \\
\hline Pisidium personatum & $\mathrm{R}$ & $R$ & & & $\mathrm{R}$ & & $\mathrm{R}$ & $\mathrm{R}$ & & & & & & & & & & & & & & & & & & & & & 9 \\
\hline Pisidium casertanum & $\mathrm{H}$ & $R$ & & & $\mathrm{H}$ & $\mathrm{H}$ & & $\mathrm{H}$ & 0 & & & $\mathrm{O}$ & & $\mathrm{R}$ & & & & & $\mathrm{O}$ & & & & $\mathrm{R}$ & $\mathrm{R}$ & $\mathrm{R} F$ & $\mathrm{R} / \mathrm{C}$ & $\mathrm{O}$ & 0 & 29 \\
\hline Celkem & 3 & 3 & 4 & 3 & 4 & 2 & 3 & 3 & 2 & 2 & 7 & 3 & 1 & 4 & 5 & $2 \mid$ & 6 & 4 & 2 & 1 & 1 & 3 & 4 & 3 & 12 & 2 & 3 & 3 & \\
\hline
\end{tabular}

\section{Poděkování}

Zabezpečení terénního výzkumu $\mathrm{v}$ roce 2003 bylo finančně podporováno z grantu Ministerstva kultury č. RK01P030MG004.

\section{Summary}

Aquatic malacofauna of the Hrubý Jeseník Mountains, the Rychlebské hory Mountains, the Zlatohorská vrchovina Highlands and the Žulovská pahorkatina Highlands (Northern Moravia, Czech Republic) was investigated in 2000, 2001 and 2003. Altogether 26 species (17 gastropods, 9 bivalves) were found at 56 localities. Species Galba truncatula, Radix peregra s.str., Ancylus fluviatilis and P. casertanum, which often inhabit springs and smaller brooks, belong to the most common molluscs in this territory. Ponds and different water bodies originated by mining enrich aquatic malacofauna of this area by e.g., Lymnaea stagnalis, Gyraulus albus, G. crista, Hippeutis complanatus, Anodonta anatina or Musculium lacustre. The finding of Ferrissia clessiniana is the first record of this non-native mollusc in the territory of Northern Moravia. Water bodies in the Vidnavské mokrriny Wetlands Nature Reserve on the Czech-Poland frontier are inhabited by molluscan community with many species living in lowlands and this community is different in comparison with molluscan communities of the other investigated localities. 


\section{Literatura}

BERAN L., 2002: Vodní měkkýši České republiky - rozšíření a jeho změny, stanoviště, šíření, ohrožení a ochrana, červený seznam [Aquatic molluscs of the Czech Republic - distribution and its changes, habitats, dispersal, threat and protection, Red List]. - Sborník př́rodovědného klubu v Uh. Hradišti, Supplementum 10, 258 pp.

BUCHAR J., 1982: Způsob publikace lokalit živočichů z území Československa. - Věšt. Čs. Společ. Zool., 46: $317-318$.

LOŽEK V., 1954: Měkkýši Hrubého Jeseníku [Moljusky Vysokovo Jesenika; Die Molluskenfauna des Altvatergebirges]. - Př́rodovědecký sborník Ostravského kraje, 15, 1: 16-65.

KAPLER O., 1956: Malakozoologické poznámky z prameniště Moravice. - Přírodovědný sborník Ostravského kraje, 17: 597-598.

KAPLER O. 1958: Příspěvek k poznání vodních měkkýšů Hrubého Jeseníku. - Přírodovědný sborník Ostravského kraje, 19: 151-152.

MÁcHA S. 1962: Měkkýši Hynčické vrchoviny [Die Weichtiere des Hynčicer Höhenzugs (Schlesien)]. - Acta Musei Silesiae, Series A, 11:1-14. 